\title{
IDENTIFIKASI FAKTOR YANG MEMPENGARUHI JENIS PEKERJAAN BERDASARKAN KARAKTERISTIK PENDUDUK DI SUMATERA BARAT
}

\author{
Widdya Rahmalina \\ Program Studi Teknik Informatika, Fakultas Teknik, Universitas Abdurrab Pekanbaru \\ Jl. Riau Ujung No.73 Pekanbaru \\ E-Mail : widdya.rahmalina@univrab.ac.id
}

\begin{abstract}
ABSTRAK
Jenis pekerjaan di Sumatera Barat diduga dipengaruhi oleh faktor daerah tempat tinggal, jenis kelamin, bidang studi, pendidikan tertinggi yang ditamatkan, dan pengalaman kerja. Untuk melihat faktor-faktor yang mempengaruhi jenis pekerjaan tersebut digunakan metode pohon klasifikasi pada Classification \& Regression Tree (CART). Metode pohon klasifikasi digunakan untuk menduga pengaruh peubah penjelas terhadap peubah respon kategorik dimulai dari pembentukan pohon awal dengan penyekatan, penentuan penyekatan terbaik, penghentian penyekatan, pemangkasan, sampai pada pemilihan pohon terbaik dan penentuan nilai dugaan respon. Data yang digunakan pada penelitian ini adalah data 6068 orang penduduk Sumatera Barat yang telah bekerja dengan pendidikan tertinggi minimal SMU sederajat yang diperoleh dari data mentah Survei Angkatan Kerja Nasional (SAKERNAS) bulan Agustus Tahun 2007. Berdasarkan hasil analisis CART dengan metode pohon klasifikasi, diperoleh pohon klasifikasi optimum yang terdiri dari 1 simpul akar, 3 simpul dalam, dan 5 simpul akhir. Simpul akar pertama kali disekat oleh peubah bidang studi, kemudian yang masuk simpul dalam adalah peubah daerah tempat tinggal, bidang studi, dan jenis kelamin. 5 simpul akhir menyatakan 5 kelompok masyarakat yang mempunyai pekerjaan utama, dimana 2 kelompok diantaranya didominasi oleh jenis pekerjaan tenaga professional, teknisi dan tenaga lain ybdi. Oleh karena itu dapat disimpulkan bahwa faktor-faktor yang mempengaruhi jenis pekerjaan penduduk Sumatera Barat adalah bidang studi, daerah tempat tinggal dan jenis kelamin.
\end{abstract}

Kata kunci: analisis CART, metode pohon klasifikasi.

\begin{abstract}
In West Sumatra, the type of works are influenced by area of residence, gender, field of study, highest educational attainment and work experience. To investigate the factors that influence the type of works are used the tree classification method on Classification and Regression Tree (CART). Tree Classification method is used to estimate the effect of the explanatory variables on the categorical response variable started from the initial tree formation with insulation, determining the best insulation, insulation termination, trimming, to the best tree selection and determination of the estimated value response. The data used in this study is the population data of West Sumatra who had been working with the highest level education of at least equivalent high school obtained from the raw data national labor survey (SAKERNAS) in August 2007. Based on the CART analysis by the tree classification method is obtained the optimum tree classification result that consists of one root node, 3 internal node, and 5 terminal node. The root node was first blocked by a variable field of study, then which include of internal node is residential areas, field of study, and gender. 5 terminal node of the stated five families with the main work, in which two groups of which is dominated by the kind of work of professionals, technicians and other related personnel. Therefore it can be concluded that the affected factors of the type of residents work in West Sumatra is a field of study, area of residence and gender.
\end{abstract}

Keywords: CART analysis, tree classification method.

\section{PENDAHULUAN}

Pekerjaan adalah suatu rangkaian tugas yang dirancang untuk dikerjakan oleh satu orang dan sebagai imbalan diberikan upah dan gaji menurut kualifikasi dan berat ringannya pekerjaan tersebut. Penduduk
Indonesia (khususnya penduduk usia kerja) bekerja dalam berbagai jenis pekerjaan yang sangat banyak jenis dan variasinya. Jenis pekerjaan adalah kumpulan pekerjaan yang mempunyai rangkaian tugas yang bersamaan. Jenis pekerjaan dalam Klasifikasi Baku Jenis 
Pekerjaan Indonesia (KBJI) adalah kumpulan pekerjaan yang cukup bersamaan tugas utamanya sehingga bisa digabungkan bersama dalam satu kelompok dalam keseluruhan sistem klasifikasi.

Ada 10 golongan pokok jenis pekerjaan menurut Klasifikasi Baku Jenis Pekerjaan Indonesia (KBJI) yaitu : (Badan Pusat Statistik, 2002)

1. Pejabat lembaga legislatif, pejabat tinggi dan manajer

2. Tenaga professional

3. Teknisi dan asisten tenaga professional

4. Tenaga tata usaha

5. Tenaga usaha jasa dan tenaga penjualan di toko dan pasar

6. Tenaga usaha pertanian dan peternakan

7. Tenaga pengolahan dan kerajinan yang berhubungan dengan itu (ybdi).

8. Operator dan perakit mesin

9. Pekerja kasar, tenaga kebersihan, dan tenaga ybdi

10. TNI dan POLRI

Setiap orang mempunyai bakat dan minat masing-masing. Bakat dan minat itulah yang akan menuntun mereka untuk memilih bidang yang mereka tekuni. Misalnya, orang yang berbakat melukis akan memilih bidang kesenian khususnya di bidang lukis, orang yang berbakat menghitung akan memilih bidang matematik, akuntansi dan sejenisnya. Bidang studi akan mempengaruhi jenis pekerjaan seseorang. Seseorang yang mempunyai bidang studi pendidikan biasanya menjadi tenaga pengajar, seseorang yang mempunyai bidang studi hukum dan politik akan menjadi seorang politisi, membuka jasa pengacara dan sejenisnya.

Selain bidang studi, jenis kelamin juga mempengaruhi jenis pekerjaan seseorang. Seorang perempuan umumnya bekerja sebagai tenaga pengajar, tenaga penjualan, pegawai sipil, tenaga kerajinan seperti batik, anyaman dan sebagainya. Seorang laki-laki umumnya bekerja sebagai pejabat lembaga legislatif, pejabat tinggi, manajer, teknisi, tenaga usaha jasa dan penjualan, operator dan perakit mesin, TNI dan POLRI sampai dengan pekerja kasar.

Daerah tempat tinggal juga menjadi salah satu faktor yang mempengaruhi jenis pekerjaan seseorang. Orang yang tinggal di pedesaan cendrung mempunyai jenis pekerjaan sebagai tenaga pertanian dan peternakan. Selain itu, masih banyak faktor lain yang mempengaruhi jenis pekerjaan seseorang seperti pendidikan terakhir yang ditamatkan, bidang studi dan sebagainya.

Dari faktor diatas, ingin dilihat faktor yang lebih mempengaruhi jenis pekerjaan penduduk Sumatera Barat. Untuk melihat faktor-faktor yang mempengaruhi jenis pekerjaan tersebut bisa dilakukan dengan mengidentifikasi jenis pekerjaan berdasarkan karakteristik penduduk. Karakteristik penduduk Sumatera Barat yang diambil dari data mentah Survei Angkatan kerja Nasional (SAKERNAS) yaitu daerah tempat tinggal, jenis kelamin, pendidikan tertinggi yang ditamatkan, bidang studi, dan pengalaman kerja.

Metode pohon klasifikasi sering digunakan untuk menduga pengaruh peubah penjelas terhadap peubah respon kategorik. Beberapa peneliti telah menggunakan metode tersebut dalam bidang kesehatan (Darsyah, M.Y., 2013) , (Sumartini, Siti Holis, 2015), dan dalam bidang kependudukan (Inayah, Riza, 2014).

\section{Rumusan Masalah}

Berdasarkan latar belakang di atas, masalah yang akan dibahas pada penelitian ini adalah bagaimana mengidentifikasi faktorfaktor yang mempengaruhi jenis pekerjaan berdasarkan karakteristik penduduk Sumatera Barat. 


\section{Batasan Masalah}

Pada pembahasan penelitian ini batasan masalah difokuskan sebagai berikut:

a. Penelitian ini terbatas pada data penduduk Sumatera Barat Bulan Agustus Tahun 2007.

b. Data penduduk juga dibatasi yaitu yang telah bekerja dan memiliki pendidikan tertinggi yang ditamatkan minimal SMU sederajat.

c. Peubah respon yakni jenis pekerjaan berdasarkan Klasifikasi Baku Jenis Pekerjaan Indonesia (KBJI) Tahun 2002.

\section{Tujuan Penelitian}

Tujuan penelitian ini adalah untuk mengidentifikasi faktor-faktor yang mempengaruhi jenis pekerjaan berdasarkan karakteristik penduduk Sumatera Barat dan untuk mengetahui kelompok penduduk berdasarkan jenis pekerjaan di Sumatera Barat.

\section{Metode CART}

CART (Classification and Regression Tree) merupakan suatu metode yang digunakan untuk menduga hubungan antara peubah penjelas dengan peubah respon dalam suatu sistem. Adapun tujuan metode pohon klasifikasi dan pohon regresi adalah untuk mengetahui peubah penjelas mana yang berpengaruh terhadap peubah respon. Metode ini dimulai pada tahun 1960 dengan program Automatic Interaction Detection (AID) yang dikembangkan oleh Morgan dan Sonquist, yang ditujukan untuk

masalah-masalah regresi dan klasifikasi dengan melalui pembentukan pohon biner. Pada tahun 1973 Breiman dan Friedman secara terpisah menggunakan metode pohon untuk masalah klasifikasi (Breiman, L, 1984).
Metode CART terdiri dari 2 cabang yaitu metode pohon klasifikasi dan pohon regresi. Metode pohon klasifikasi digunakan untuk menduga pengaruh peubah penjelas terhadap peubah respon kategorik. Algoritma lain yang dapat digunakan untuk menduga pengaruh peubah penjelas terhadap peubah respon kategorik adalah GDA (Generalized Discriminant Function Analysis). Sedangkan metode pohon regresi merupakan metode alternatif dari GLM (Generalized Linear Models) dan GRM (Generalized Regression Models) yang digunakan untuk menduga pengaruh peubah penjelas terhadap peubah respon kontinu.

Analisis data pada metode ini dilakukan melalui suatu prosedur iteratif, sehingga bila dilakukan secara manual, tentulah sangat rumit dan lama. Namun, dengan adanya perkembangan teknologi komputer, perhitungan dapat dilakukan dengan cepat dan mudah.

Metode CART diawali dengan melakukan penyekatan biner (binary splitting) terhadap keseluruhan pengamatan yang berada pada simpul akar menjadi 2 bagian yang dinamakan sebagai simpul anak. Pada tahap selanjutnya, setiap simpul anak ini akan menjadi simpul induk baru yang akan disekat lagi menjadi 2 simpul anak baru. Demikian seterusnya sampai diperoleh simpul-simpul yang tidak dapat disekat lagi. Hasil dari prosedur penyekatan pada CART ini disajikan dalam suatu diagram pohon seperti pada Gambar 1. 


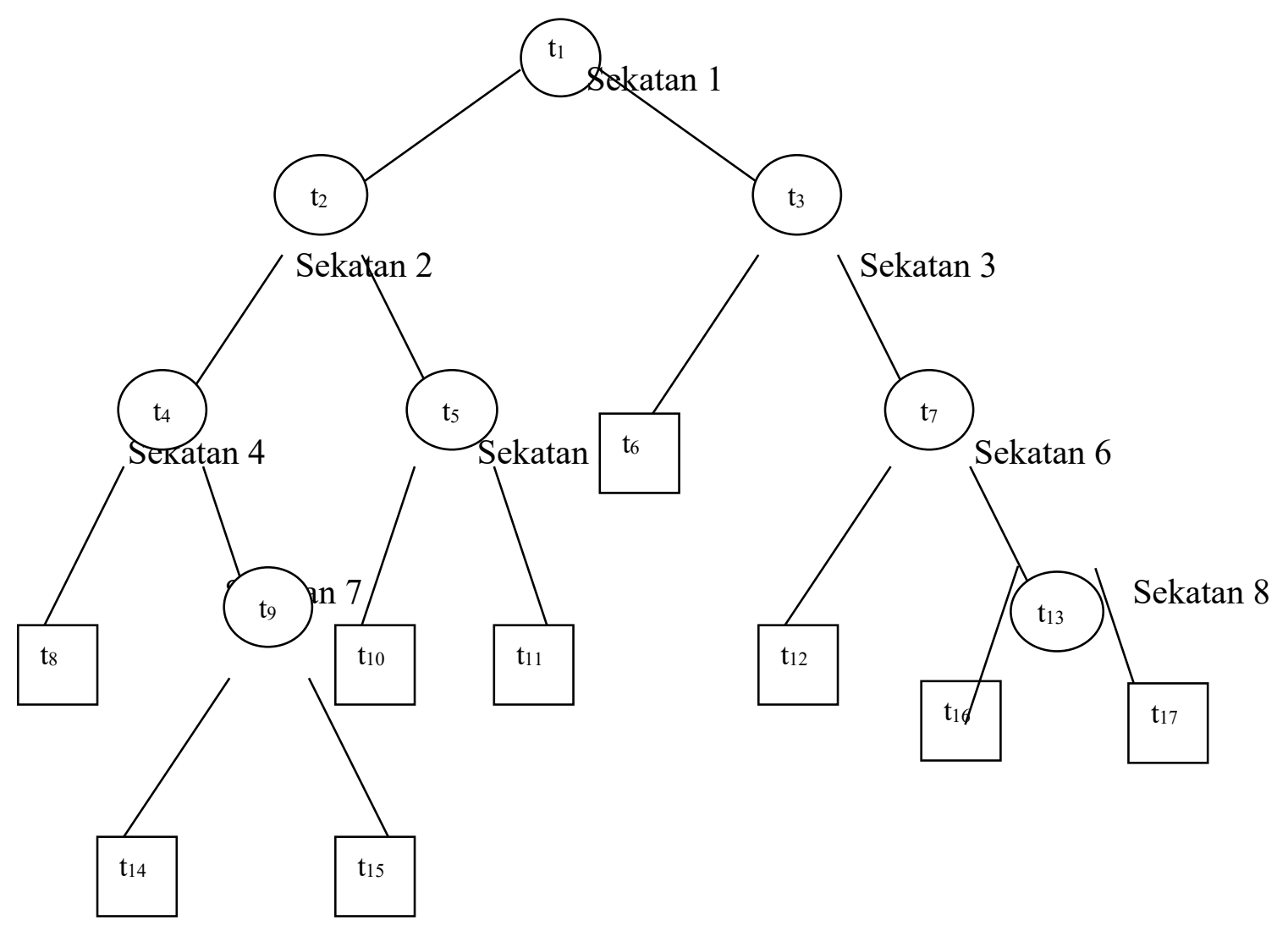

Gambar 1. Struktur Pohon Klasifikasi

\section{Pembentukan Pohon Klasifikasi}

Pembentukan pohon, baik klasifikasi maupun regresi dalam metode ini dilakukan berdasarkan penyekatan terhadap ruang peubah penjelas. Penyekatan yang dibentuk pada pohon regresi dilakukan dengan mempertimbangkan tingkat kehomogenan respon dalam setiap simpul. Sedangkan pada pohon klasifikasi, penyekatan dibentuk berdasarkan nilai perubahan impurity yang maksimum pada setiap simpul.

Langkah-langkah membuat pohon klasifikasi dalam metode CART adalah sebagai berikut :

1. Pembentukan pohon awal, terbagi atas a. Menentukan penyekatan setiap simpul

b. Menentukan penyekatan terbaik

c. Menentukan simpul akhir atau penghentian penyekatan

2. Pemangkasan

3. Pemilihan pohon terbaik

4. Menentukan nilai dugaan setiap simpul akhir.

\section{Pembentukan Pohon Awal dengan} Penyekatan

Elemen yang dibutuhkan dalam proses pembentukan pohon awal adalah :

1. Himpunan $Q$ yang berisi pertanyaanpertanyaan biner dalam bentuk $\{$ Apakah $\boldsymbol{x} \in \boldsymbol{A}\}$ dan $\boldsymbol{A} \subset \boldsymbol{X}$ 
2. Kriteria kebaikan sekatan $\phi(s, t)$ yang akan dievaluasi untuk setiap sekatan $s$ dan simpul $t$

Himpunan $Q$ yang berisi pertanyaan-pertanyaan biner dalam bentuk \{apakah $\boldsymbol{x} \in \boldsymbol{A}$ \} menghasilkan himpunan $S$ dari sekatan-sekatan $s$ pada tiap simpul $t$ dan misalkan $\boldsymbol{A} \subset \boldsymbol{X}$ dimana $X$ adalah ruang peubah penjelas, $A$ adalah himpunan sekatan dan $x$ adalah

\section{Aturan Penyekatan}

Proses penyekatan setiap simpul dilakukan dengan cara mencari semua kemungkinan penyekatan pada setiap peubah penjelas. Kemudian dicari penyekatan terbaik dari himpunan sekatan tersebut.

Penyekatan dapat dilakukan dengan aturan sebagai berikut :(Breiman, L, 1984)

1. Tiap sekatan hanya bergantung pada nilai yang berasal dari satu peubah penjelas.

2. Untuk peubah kontinu $x_{m}$, penyekatan yang diperbolehkan adalah untuk $\quad x_{m} \leq t$ dan $x_{m}>t$, dimana $t$ adalah nilai tengah antara 2 amatan secara berurutan. Jika ada $n$ ruang contoh pada peubah kontinu, maka terdapat $n-1$ penyekatan.

Contoh 1 :

Peubah respon $\mathrm{Y}$ dengan peubah penjelas A (kontinu dengan nilai $a_{1}, a_{2}, a_{3}, a_{4}, a_{5}$ ) diurutkan menaik. Peubah penjelas A memiliki kemungkinan sekatan 4, dengan penyekatan sebagai berikut :

Tabel 1. Penyekatan Ruang Contoh Kontinu

Penyekatan Ruang Contoh Berdasarkan Peubah A

\begin{tabular}{llll}
\hline No & Nilai t & Simpul Kiri & Simpul \\
\hline
\end{tabular}

3. Aturan penghentian penyekatan

4. Pendugaan respon untuk setiap amatan pada simpul-simpul akhir.

suatu amatan. Untuk jawaban "ya" maka amatan dalam simpul $t$ dimasukkan ke sekatan $A$ dan untuk jawaban "tidak" maka amatan dalam simpul $t$ dimasukkan ke sekatan $\boldsymbol{A}^{\boldsymbol{c}}$, dimana $\boldsymbol{A}^{\boldsymbol{c}}$ adalah komplemen dari $A$ dalam X.

\begin{tabular}{|c|c|c|c|}
\hline & & & Kanan \\
\hline 1 & $\begin{array}{c}\left(a_{1}+a_{2}\right. \\
) / 2\end{array}$ & $\left\{a_{1}\right\}$ & $\begin{array}{l}\left\{a_{2}, a_{3}, a_{4},\right. \\
\left.a_{5}\right\}\end{array}$ \\
\hline 2 & $\begin{array}{c}\left(a_{2}+a_{3}\right. \\
) / 2\end{array}$ & $\left\{a_{1}, a_{2}\right\}$ & $\left\{a_{3}, a_{4}, a_{5}\right.$ \\
\hline 3 & $\begin{array}{c}\left(a_{3}+a_{4}\right. \\
) / 2\end{array}$ & $\left\{a_{1}, a_{2}, a_{3}\right.$ & $\left\{a_{4}, a_{5}\right\}$ \\
\hline 4 & $\begin{array}{c}\left(a_{4}+a_{5}\right. \\
) / 2\end{array}$ & $\begin{array}{l}\left\{a_{1}, a_{2}, a_{3},\right. \\
\left.a_{4}\right\}\end{array}$ & $\left\{a_{5}\right\}$ \\
\hline
\end{tabular}

3. Untuk peubah kategorik $x_{m}$ ordinal mempunyai taraf $L$ maka terdapat $L-1$ penyekatan, dan $x_{m}$ nominal mempunyai taraf $L$, maka terdapat $2^{L-}$

1-1 penyekatan.

Contoh 2 :

Peubah respon $\mathrm{Y}$ dengan peubah penjelas $\mathrm{B}$ (ordinal dengan nilai terurut $\left\{b_{1}, b_{2}, b_{3}, b_{4}\right\}$ ), dan $\mathrm{C}$ (nominal dengan nilai terurut $\left.\left\{c_{1}, c_{2}, c_{3}\right\}\right)$. Kemungkinan sekatan pada $\mathrm{B}$ adalah 3, dan pada $\mathrm{C}$ adalah 3 .

Tabel 2. Penyekatan Ruang Contoh Ordinal dan Nominal

Penyekatan Ruang Contoh Berdasarkan Peubah B dan C

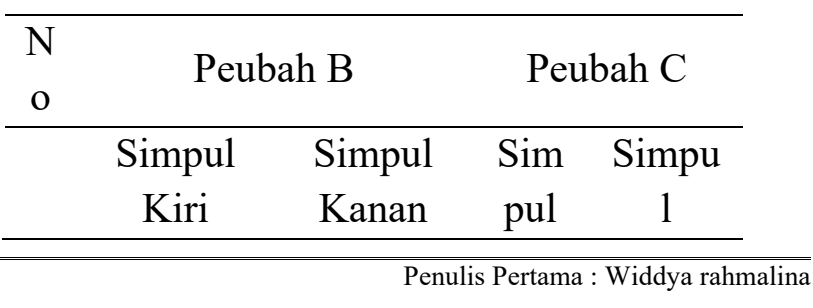




\begin{tabular}{|c|c|c|c|c|}
\hline & & & Kiri & Kanan \\
\hline 1 & $\left\{b_{1}\right\}$ & $\begin{array}{l}\left\{b_{2}, b_{3},\right. \\
\left.b_{4}\right\}\end{array}$ & $\left\{c_{1}\right.$ & $\left\{c_{2}, c_{3}\right.$ \\
\hline 2 & $\left\{b_{1}, b_{2}\right.$ & $\left\{b_{3}, b_{4}\right.$ & $\left\{c_{2}\right.$ & $\begin{array}{l}\left\{c_{1}, c_{3}\right. \\
\}\end{array}$ \\
\hline 3 & $\begin{array}{l}\left\{b_{1}, b_{2},\right. \\
\left.b_{3}\right\}\end{array}$ & $\left\{b_{4}\right\}$ & $\left\{c_{3}\right.$ & $\left\{c_{1}, c_{2}\right.$ \\
\hline
\end{tabular}

\section{Kriteria Kebaikan Sekatan (Good of Split Criterion)}

Kemungkinan sekatan yang dapat terbentuk pada suatu simpul sangat banyak, sehingga sulit menafsirkan peubah penjelas mana yang paling mempengaruhi peubah respon. Oleh karena itu, harus dipilih sekatan terbaik diantara kumpulan sekatan dari setiap pengamatan. Pemilihan sekatan terbaik dilakukan dengan menggunakan kriteria gini (gini criterion) yang dihitung berdasarkan pada nilai perubahan impurity yang maksimum.(Breiman, L, 1984)

Misalkan $\boldsymbol{p}(\boldsymbol{j} \mid \boldsymbol{t})$ adalah peluang peubah respon kategori ke- $j(j=1,2, \ldots, J ; j$ adalah banyak kategori peubah respon) pada simpul ke- $t$, sehingga Simpul $t$ disekat oleh sekatan $s$ dengan penyekatan biner menjadi simpul $t_{L}$ dan $t_{R}$. Penyekatan dibentuk dari pertanyaan bahwa \{Apakah $\left.\boldsymbol{x}_{\boldsymbol{i}} \in \boldsymbol{A}\right\}$ dan $\boldsymbol{A} \subset \boldsymbol{X}$, jika "ya" maka semua amatan $\boldsymbol{x}_{\boldsymbol{i}}$ masuk ke simpul $t_{L}$ dan jika "tidak" maka semua amatan $\boldsymbol{x}_{\boldsymbol{i}}$ masuk ke simpul $t_{R}$. Misalkan proporsi pengamatan yang masuk ke simpul $t_{L}$ adalah $P_{L}$ dan proporsi pengamatan yang masuk pada simpul $t_{R}$ adalah $P_{R}$.

Definisikan fungsi impurity pada simpul $t, I(t)$, sebagai fungsi dari $p(j \mid t)$; $(j=1,2, \ldots, J)$ yaitu :

$$
I(t)=\phi(p(1 \mid t), \ldots, p(J \mid t))
$$

Dengan kriteria gini, fungsi impurity tersebut didefinisikan sebagai :

$$
I(t)=\sum_{j \neq i} p(j \mid t) p(i \mid t) .
$$

yang dapat ditulis sebagai :

$$
I(t)=1-\sum_{j} p^{2}(j \mid t)
$$

Jika $s$ adalah sekatan pada simpul $t$, $P_{L}$ dan $P_{R}$ masing-masing adalah proporsi amatan yang masuk ke simpul $t_{L}$ dan $t_{R}$ serta $I\left(t_{L}\right)$ dan $I\left(t_{R}\right)$ masing-masing adalah impurity pada simpul $t_{L}$ dan $t_{R}$. Maka perubahan impurity akibat penyekatan $t$ menjadi menjadi $t_{L}$ dan $t_{R}$ oleh sekatan $s$ adalah :

$$
\Delta I(s, t)=I(t)-P_{R} I\left(t_{R}\right)-P_{L} I\left(t_{L}\right)
$$

Sekatan terbaik dari himpunan sekatan $\mathrm{S}$ adalah sekatan $s^{*}$ yang dapat memaksimumkan perubahan impurity atau $\mathrm{s}^{*}$ sehingga :

$$
\Delta I\left(s^{*}, t\right)=\underset{s \in S}{\operatorname{Max}} \Delta I(s, t)
$$

\section{Proses Penghentian Penyekatan}

Setelah melakukan beberapa tahap penyekatan terhadap simpul-simpul, maka proses penyekatan akan dihentikan bila ditemui salah satu keadaan sebagai berikut

: (Breiman, L, 1984)

1 .

ila jumlah amatan pada setiap simpul kurang dari jumlah amatan minimum yang ditetapkan.

2.

emua amatan pada simpul anak mempunyai sebaran nilai dugaan yang mengakibatkan penyekatan tidak mungkin dilanjutkan.

3.

ika nilai perubahan impurity simpul pada setiap peubah penjelas sudah kecil dari nilai batas impurity minimum yang telah ditentukan. 
Misalkan $\beta>0$ adalah nilai batas minimum impurity maka penyekatan akan berhenti jika $\underset{\boldsymbol{s} \in \boldsymbol{S}}{\operatorname{Max}} \Delta \boldsymbol{I}(\boldsymbol{s}, \boldsymbol{t})<\beta$

\section{Pemangkasan}

Karena penghentian penyekatan dilakukan berdasarkan perubahan impurity, maka pohon yang terbentuk dapat berukuran sangat besar. Semakin banyak sekatan, semakin besar pohon yang dihasilkan dengan tingkat kesalahan yang kecil. Namun, semakin besar pohon, interpretasi menjadi semakin sulit. Sebaliknya jika sekatan sedikit, pohon yang dihasilkan tidak besar dan mudah menginterpretasikannya, tetapi tingkat kesalahannya besar. Untuk menghindari kedua kondisi ekstrim di atas maka dicari pohon dengan ukuran yang layak.

Pemilihan pohon dengan ukuran yang layak dapat dilakukan dengan langkah sebagai berikut : (Breiman, L, 1984)

1. Penentuan pohon awal yang besar

2. Secara iteratif pohon tersebut dipangkas (pruning) menjadi sekuen pohon yang semakin kecil.

3. Pilih pohon terbaik dari sekuen tersebut dengan menggunakan contoh uji (test sample) atau contoh validasi silang (cross validation sample).

Pemangkasan pada pohon klasifikasi dilakukan dengan menggunakan ukuran biaya kompleksitas (CostComplexity) minimum. Pendefinisian pohon besar yang dibentuk dari prosedur penyekatan adalah $T_{\max }$. Pemangkasan dilakukan bukan terhadap $T_{\max }$ tetapi terhadap $T_{1}$ yaitu pohon terkecil yang memenuhi kondisi : $R\left(T_{\max }\right)=R\left(T_{1}\right)$.
Untuk mendapatkan $T_{1}$ dari $T_{\max }$ dilakukan evaluasi terhadap semua $t_{L}$ dan $t_{R}$ yang merupakan simpul akhir dari pohon besar $T_{\max }$. Jika $R(t)=R\left(t_{L}\right)+R\left(t_{R}\right)$, maka pangkas kedua simpul akhir tersebut sampai tidak ada lagi yang mungkin untuk diperoleh, sehingga diperoleh $T_{1}$.

Secara umum untuk sembarang $T$ yang merupakan sub pohon dari $T_{\max }$ dapat didefinisikan suatu ukuran biaya kompleksitas sebagai berikut :

$$
\boldsymbol{R}_{\alpha}(\boldsymbol{T})=\boldsymbol{R}(\boldsymbol{T})+\alpha|\widetilde{\boldsymbol{T}}|
$$

dimana :

$\boldsymbol{R}_{\alpha}(\boldsymbol{T})=$ ukuran biaya kompleksitas

$R(T)=$ nilai kesalahan

pengelompokkan dari pohon pada biaya kompleksitas simpul akhir

$|\widetilde{\boldsymbol{T}}| \quad=$ banyak simpul akhir pada pohon $\mathrm{T}$

$\alpha=$ parameter biaya kompleksitas Untuk setiap $t \quad \epsilon \quad T$ kesalahan pengelompokan pada simpul $T$ didefinisikan :

$$
r(t)=1-\max _{j} p(j \mid t)
$$

kemudian ditulis :

$$
R(t)=r(t) p(t)
$$

dimana

$$
\begin{aligned}
& p(t)=\sum_{j} p(j, t)=\sum_{j} \frac{\pi(j) N_{j}(t)}{N_{j}}=\sum_{j} \frac{N_{j} \cdot N_{j}(t)}{N \cdot N_{j}}=\sum_{j} \frac{N_{j}(t)}{N} \\
& =\frac{N_{1}(t)}{N}+\frac{N_{2}(t)}{N}+\ldots+\frac{N_{J}(t)}{N} \\
& p(t)=\frac{N(t)}{N}
\end{aligned}
$$

Kesalahan pengelompokkan untuk semua simpul $t$ pada pohon $T$ adalah :

$$
R(T)=\sum_{t^{\prime} \in \widetilde{T}} R\left(t^{\prime}\right)
$$


Proses pemangkasan minimum merupakan pemotongan jalur terlemah (weakest link). Untuk setiap $T_{t}$ yang merupakan simpul dalam dari $T_{1}$, ukuran biaya kompleksitasnya dapat didefinisikan sebagai :

$$
R_{\alpha}\left(T_{t}\right)=R\left(T_{t}\right)+\alpha\left|\widetilde{T}_{t}\right|
$$

Sedangkan biaya kompleksitas dari simpul dalam $t \in T_{1}$ dapat didefinisikan sebagai :

$$
R_{\alpha}(\{t\})=R(t)+\alpha
$$

Selama $R_{\alpha}\left(T_{t}\right)<R_{\alpha}(\{t\})$, cabang $T_{t}$ memiliki biaya kompleksitas lebih kecil dari simpul tunggal $\{t\}$. Tapi untuk suatu simpul t tertentu, nilai $R_{\alpha}\left(T_{t}\right)$ sama dengan nilai $R_{\alpha}(\{t\})$, tergantung dari nilai kritis $\alpha$. Nilai kritis dari $\alpha$ diperoleh dengan menyamakan kedua nilai kompleksitas tersebut yang dapat didefinisikan sebagai :

$$
\alpha=\frac{R(t)-R\left(T_{t}\right)}{\left|\widetilde{T}_{t}\right|-1}
$$

Kemudian didefinisikan suatu fungsi $h_{1}(t)$, $t \in T_{1}$ yaitu :

$$
h_{1}(t)=\left\{\begin{array}{l}
\frac{R(t)-R\left(T_{t}\right)}{\left|\widetilde{T}_{t}\right|-1}, t \notin \widetilde{T}_{1} \\
+\infty,
\end{array} \quad t \in \widetilde{T}_{1} .\right.
$$

Sehingga jalur terlemah dalam simpul $T_{1}$ dilambangkan dengan $\bar{t}_{1}$ merupakan simpul yang memenuhi kriteria :

$$
h_{1}\left(\bar{t}_{1}\right)=\min _{t \in T_{t}} h_{1}(t)
$$

Nilai parameter kompleksitas yang memenuhi untuk persamaan tersebut didefinisikan sebagai :

$$
\alpha_{2}=h_{1}\left(\bar{t}_{1}\right) \text {. }
$$

)

Kemudian dibentuk pohon baru dengan cara memangkas cabang $T_{\bar{t}_{1}}$ yang merupakan cabang dari simpul dalam $T_{1}$ yang memiliki simpul utama $\left\{\bar{t}_{1}\right\}$. Hasil pemangkasan ini adalah $T_{2}$ yaitu :

$$
T_{2}=T_{1}-T_{\bar{t}_{1}}
$$

)

Sehingga $T_{2}$ merupakan sub pohon yang memenuhi kriteria biaya kompleksitas minimum dengan parameter kompleksitas bernilai $\alpha_{2}$.

Demikian selanjutnya dengan cara yang sama tentukan jalur terlemah dalam $T_{2}$ dan seterusnya. Akan didapatkan sub pohon yang tersarang yaitu $\left\{T_{1}, T_{2}, T_{3}, \ldots,\{t\}\right\}$ dengan hubungan $T_{1}>T_{2}>T_{3}>\ldots>\{t\}$ dan himpunan ukuran kompleksitas $\left\{\alpha_{1}, \alpha_{2}, \alpha_{3}, \ldots\right\} \quad$ dengan hubungan $\alpha_{1}<\alpha_{2}<\alpha_{3}<\ldots$

Jika terdapat jalur terlemah yang sama pada langkah ke- $k, k=1,2,3, \ldots$, misal $h_{k}\left(\bar{t}_{k}\right)=h_{k}\left(\bar{t}_{k}^{\prime}\right) \quad$ maka pemangkasan dilakukan dengan cara :

$$
T_{k+1}=T_{k}-\left(T_{\bar{t}_{k}}-T_{\bar{t}_{k}^{\prime}}\right) \text {. }
$$

\section{Pemilihan Pohon terbaik}

Setelah dilakukan pemangkasan, maka harus dipilih pohon terbaik dari himpunan cabang pohon yang sudah dipangkas. Pemilihan pohon terbaik dapat dilakukan dengan dua cara yaitu :

\section{Dugaan contoh uji (test sample estimate)}

Test sample estimate dinotasikan dengan $\boldsymbol{R}^{t s}(\boldsymbol{T})$. Untuk memperoleh nilai $\boldsymbol{R}^{t s}(\boldsymbol{T})$ maka amatan $L$ dibagi menjadi dua secara acak yaitu $L_{l}$ sebagai learning sample dan $L_{2}$ sebagai test sample. $L_{1}$ digunakan untuk menentukan sekuens pohon $\left\{\boldsymbol{T}_{\boldsymbol{k}}\right\}$ dengan urutan yaitu 
$T_{1}>T_{2}>\ldots>\left\{t_{1}\right\} \quad$ yang melalui pemangkasan. Sedangkan $L_{2}$ digunakan untuk menentukan $\boldsymbol{R}^{t s}\left(\boldsymbol{T}_{\boldsymbol{k}}\right)$. Jika $L_{2}$ berukuran $N^{(2)}$, maka :

$$
\boldsymbol{R}^{t s}(\boldsymbol{T})=\frac{1}{\boldsymbol{N}^{(2)}} \sum_{i, j} \boldsymbol{c}(\boldsymbol{i} \mid \boldsymbol{j}) \boldsymbol{N}_{i j}^{(2)}
$$

dimana $\boldsymbol{R}^{\boldsymbol{t s}}(\boldsymbol{T})=$ nilai dugaan berdasarkan total kesalahan pengelompokkan pada $\mathrm{T}$.

Pohon terbaik adalah $T_{k 0}$, dengan kriteria sebagai berikut :

$$
\boldsymbol{R}^{t s}\left(\boldsymbol{T}_{k 0}\right)=\min _{k} \boldsymbol{R}^{t s}\left(\boldsymbol{T}_{k}\right)
$$

\section{2. validasi silang (cross- validation estimates)}

Untuk menentukan cross-validated estimate yaitu dengan $v$-fold, jika amatan $L$ berukuran $N$ yang dibagi secara acak menjadi $V$ kelompok, yaitu $L_{1}, L_{2}, \ldots, L_{v}$ yang berukuran sama. Learning sample ke$v$ adalah $L^{(v)}=L-L_{v}, v=1,2, \ldots, V$ yang digunakan untuk membentuk urutan pohon $\left\{\boldsymbol{T}_{\boldsymbol{k}}\right\}$ dan urutan parameter kompleksitas $\left\{\alpha_{\boldsymbol{k}}\right\}$. Sehingga diperoleh $v$ urutan $\left\{\boldsymbol{T}_{\boldsymbol{k}}\right\}$ dan $v$ urutan $\left\{\alpha_{k}\right\}$, kemudian dengan menggunakan amatan $L$ dapat dibentuk urutan $\left\{\boldsymbol{T}_{\boldsymbol{k}}\right\}$ dan urutan $\left\{\alpha_{\boldsymbol{k}}\right\}$. Biaya kompleksitas minimum pada pohon dari amatan ke- $L$ berukuran $N$ adalah :

$$
\boldsymbol{R}^{c v}(\boldsymbol{T}(\alpha))=\frac{1}{N} \sum_{i, j} \boldsymbol{c}(\boldsymbol{i} \mid \boldsymbol{j}) \boldsymbol{N}_{i j} \ldots .(21)
$$

dimana sama dengan biaya kompleksitas minimum $T_{k}$ untuk $\alpha_{k} \leq \alpha \leq \alpha_{k+1}$. Definisikan $\alpha_{k}^{\prime}=\sqrt{\alpha_{k} \alpha_{k+1}}$ sehingga $\alpha_{k}^{\prime}$ adalah nilai tengah pada parameter biaya kompleksitas yang mengakibatkan $\boldsymbol{T}(\alpha)=\boldsymbol{T}_{k}$, maka diperoleh :

$$
\boldsymbol{R}^{c v}\left(\boldsymbol{T}_{k}\right)=\boldsymbol{R}^{c v}\left(\boldsymbol{T}\left(\alpha_{k}^{\prime}\right)\right)
$$

dimana $\boldsymbol{R}^{c \boldsymbol{v}}\left(\boldsymbol{T}_{\boldsymbol{k}}\right)=$ nilai dugaan pada test sample $L_{v}$ dan pohon $\boldsymbol{T}^{(v)}\left(\alpha_{k}^{\prime}\right)$.

Pohon terbaik adalah $T_{k 0}$, yaitu :

$$
\boldsymbol{R}^{c v}\left(\boldsymbol{T}_{k 0}\right)=\min _{k} \boldsymbol{R}^{c v}\left(\boldsymbol{T}_{k}\right)
$$

dimana $\boldsymbol{R}^{c \boldsymbol{v}}\left(\boldsymbol{T}_{\boldsymbol{k} 0}\right)$ adaldh $\left.{ }^{9}\right)$ nilai dugaan kesalahan pengelompokkan.

\section{Penentuan Nilai Dugaan Respon}

Setiap simpul dimulai dari simpul induk yang ditentukan nilai dugaannya. Nilai dugaan 'pảdả..(20) bergantung pada beberapa faktor, yaitu :

1. Asumsikan peluang awal setiap simpul dalam kelompok data

2. Fungsi subjek pada setiap hasil dalam kelompok data yang berakhir pada setiap simpul.

Misalkan $j \in\{1,2, \ldots, J\} \quad$ adalah kelompok dugaan dan simpul akhir $\boldsymbol{t} \in \tilde{\boldsymbol{T}}$ dengan $\tilde{\boldsymbol{T}}$ adalah sub pohon T, maka nilai dugaan pada simpul akhir $\boldsymbol{t} \in \tilde{\boldsymbol{T}}$ dinotasikan dengan $\hat{\boldsymbol{j}}(\boldsymbol{t})$. Aturan penentuan nilai dugaan, yaitu :

$$
\hat{j}(t)=\max _{j} P(j \mid t)
$$

Misalkan $\hat{\boldsymbol{j}}(\boldsymbol{t})$ dikatakan nilai dugaan pada simpul $t$ jika $\boldsymbol{P}(\boldsymbol{j} \mid \boldsymbol{t})=\max _{i} \boldsymbol{P}(\boldsymbol{i} \mid \boldsymbol{t})$ maka $\hat{\boldsymbol{j}}(\boldsymbol{t})=\boldsymbol{j}$. Jika dua atau lebih kelompok maksimum yang berbeda maka $\hat{\boldsymbol{j}}(\boldsymbol{t})$ juga maksimum.

\section{METODE}

Pada penelitian ini data yang diambil adalah data karakteristik penduduk Sumatera Barat yang bekerja dengan klasifikasi jenis pekerjaan yang telah ditetapkan Badāi..P Püäàt ${ }^{2}$ Statistik Pusat. Data ini berukuran 6068 orang penduduk yang bersumber dari data Survei Angkatan 
Kerja Nasional (SAKERNAS) Bulan Agustus Tahun 2007 yang diperoleh dari Badan Pusat Statistik (BPS) Propinsi Sumatera Barat. Peubah-peubah yang diamati dalam penelitian ini terdiri dari peubah respon yaitu jenis pekerjaan dan peubah penjelas yaitu daerah tempat tinggal, jenis kelamin, pendidikan tertinggi yang ditamatkan minimal SMU sederajat, jurusan pendidikan/bidang studi, dan pengalaman kerja.

Untuk memudahkan dalam mengolah data, maka peubah-peubah yang berkaitan perlu dikodekan.

Tabel 3. Pengkodean peubah

\begin{tabular}{|c|c|c|c|}
\hline Peubah & $\begin{array}{c}\text { Jenis } \\
\text { Peubah }\end{array}$ & Nilai & Kode \\
\hline \multirow{12}{*}{$\begin{array}{l}\text { Jenis } \\
\text { Pekerjaan }\end{array}$} & \multirow{12}{*}{$\begin{array}{l}\text { Peubah } \\
\text { Respon }\end{array}$} & Tenaga Profesional, Teknisi dan Tenaga Lain & \\
\hline & & Ybdi & 1 \\
\hline & & Tenaga Kepemimpinan dan Ketatalaksanaan & 2 \\
\hline & & Pejabat Pelaksana, Tenaga Tata Usaha dan & \\
\hline & & Tenaga Ybdi & 3 \\
\hline & & Tenaga Usaha Penjualan & 4 \\
\hline & & Tenaga Usaha Jasa & 5 \\
\hline & & TU Tani, Kebun, Ternak, Ikan, Hutan dan & \\
\hline & & Perburuan & 6 \\
\hline & & TNI dan POLRI & 7 \\
\hline & & Tenaga Produksi Op.Alat Angkutan dan Pekerja & \\
\hline & & Kasar & 8 \\
\hline \multirow[t]{3}{*}{ Daerah } & Peubah & Perkotaan & 0 \\
\hline & Penjela & & \\
\hline & $\mathrm{s}$ & Pedesaan & 1 \\
\hline Jenis & Peubah & & \\
\hline \multirow[t]{2}{*}{ Kelamin } & Penjela & Laki-laki & 0 \\
\hline & $\mathrm{S}$ & Perempuan & 1 \\
\hline Pendidikan & Peubah & SMU & 1 \\
\hline Tertinggi & Penjela & & \\
\hline Yang & $\mathrm{S}$ & SMK & 2 \\
\hline \multirow[t]{3}{*}{ Ditamatkan } & & Diploma I/II & 3 \\
\hline & & Akademi/Diploma III & 4 \\
\hline & & Diploma IV/S1/S2 & 5 \\
\hline Bidang & Peubah & & \\
\hline \multirow[t]{5}{*}{ Studi } & Penjela & Agama dan Ilmu Ketuhanan & 1 \\
\hline & $\mathrm{S}$ & Administrasi/Manajemen Bisnis & 2 \\
\hline & & Administrasi/Manajemen Keuangan & 3 \\
\hline & & Administrasi Pemerintahan & 4 \\
\hline & & Administrasi/Manajemen Perkantoran & 5 \\
\hline
\end{tabular}


Arsitektur dan Perencanaan Kota 6

Bahasa dan Sastra 7

Ekonomi 8

Hukum dan Kehakiman 9

Humanisme/Humaniora 10

Ilmu Pengetahuan Alam (IPA) 11

Ilmu Sosial dan Politik (IPS) 12

Kedokteran dan Kesehatan 13

Kehutanan 14

Kesenian dan Seni Rupa $\quad 15$

Komunikasi Massa dan Dokumentasi 16

Matematika dan Ilmu Komputer $\quad 17$

Pelayanan Jasa $\quad 18$

Perikanan $\quad 19$

Pertanian 20

Pertukangan, Kerajinan dan Industri 21

Peternakan 22

Psikologi 23

Teknik/Teknologi 24

Transportasi dan Komunikasi 25

Kependidikan dan Keguruan $\quad 26$

Lainnya 27

IPA SMU 28

IPS SMU $\quad 29$

Fisika SMU $\quad 30$

Biologi SMU 31

Bahasa dan Satra SMU 32

Listrik, Mesin, Grafika, Tekstil, Penerbangan dan lainnya (STM) 33

Ekonomi, Akuntansi, dan Tata Niaga (SMEA) 34

Tata Boga, Tata Busana, dan Tata Graha

(SMKK) 35

Perhotelan, Pariwisata, Perawat dan lainnya

\begin{tabular}{lllc} 
& & $(\mathrm{SMK})$ & 36 \\
\hline Pengalama & Peubah & Ya & 0 \\
n Kerja & Penjela & & \\
& s & Tidak & 1 \\
\hline
\end{tabular}

Analisis data dilakukan dengan metode CART dengan langkah-langkah sebagai berikut :
1. Pembentukan pohon awal dengan penyekatan menggunakan kriteria Gini (Gini Criterion), dengan 
menetapkan nilai batas impurity minimum 0,0001.

2. Penentuan penyekatan terbaik berdasarkan perubahan impurity yang maksimum.

3. Penghentian penyekatan jika maksimum kurang dari nilai batas impurity minimum.

4. Pemangkasan terhadap pohon yang berukuran besar dengan menggunakan ukuran biaya kompleksitas (Cost-Complexity) minimum.

5. Pemilihan pohon terbaik dari himpunan yang terbentuk akibat pemangkasan, dengan menggunakan kriteria dugaan contoh uji (test sample estimate) atau contoh validasi silang (cross validation sample).

6. Penentuan nilai dugaan respon.

Pengolahan data dilakukan dengan bantuan Software SPSS versi 16 dan CART versi 4.0 .

\section{HASIL}

Hasil analisis CART yaitu pohon klasifikasi dengan penyekatan untuk jenis pekerjaan di Propinsi Sumatera Barat dapat dilihat pada gambar berikut :

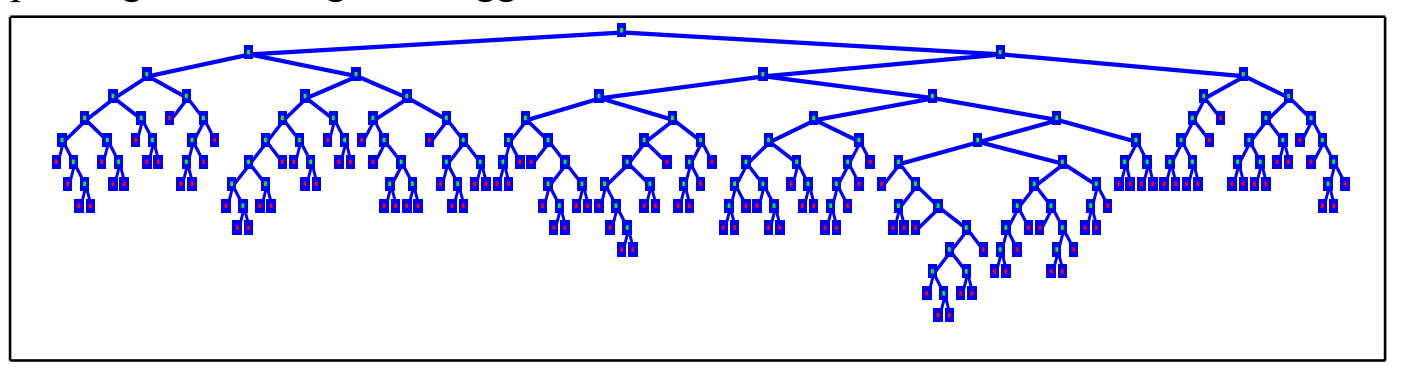

Gambar 2. Pohon klasifikasi awal

Pohon awal yang terbentuk memberikan 115 buah simpul akhir. Pohon yang terbentuk sangat besar sehingga sulit untuk menginterpretasi hasilnya. Oleh karena itu dilakukan pemangkasan, dengan tujuan agar pohon memiliki struktur sederhana dan informasi yang dibutuhkan tidak hilang. Metode pemangkasan yang digunakan adalah validasi silang lipat 10. Pada Tabel 4 memperlihatkan Cross Validated Relative Error yang terbentuk dari hasil pemangkasan.

Tabel 4. Kesalahan relatif validasi silang

\begin{tabular}{|c|c|c|c|c|}
\hline $\begin{array}{l}\text { Tree } \\
\text { Num } \\
\text { ber }\end{array}$ & $\begin{array}{c}\text { Termi } \\
\text { nal } \\
\text { Node } \\
\text { s }\end{array}$ & $\begin{array}{c}\text { Cross- } \\
\text { Validated } \\
\text { Relative } \\
\text { Cost }\end{array}$ & $\begin{array}{c}\text { Resu } \\
\text { bstitu } \\
\text { tion } \\
\text { Relati } \\
\text { ve } \\
\text { Cost }\end{array}$ & Complexity \\
\hline 1 & 115 & $\begin{array}{l}0.73 \pm \\
0.0096\end{array}$ & 0.64 & -1.00 \\
\hline 2 & 112 & $\begin{array}{l}0.73 \pm \\
0.0096\end{array}$ & 0.64 & 0.00011 \\
\hline 3 & 106 & $\begin{array}{c}0.73 \pm \\
0.0096\end{array}$ & 0.65 & 0.00015 \\
\hline 4 & 101 & $\begin{array}{l}0.73 \pm \\
0.0096\end{array}$ & 0.65 & 0.00017 \\
\hline 5 & 96 & $\begin{array}{l}0.73 \pm \\
0.0097\end{array}$ & 0.65 & 0.00019 \\
\hline 6 & 91 & $0.73 \pm$ & 0.65 & 0.00020 \\
\hline
\end{tabular}




\begin{tabular}{|c|c|c|c|c|c|c|c|c|c|}
\hline $\begin{array}{c}\text { Tree } \\
\text { Num } \\
\text { ber }\end{array}$ & $\begin{array}{l}\text { Termi } \\
\text { nal } \\
\text { Node } \\
\text { s }\end{array}$ & $\begin{array}{c}\text { Cross- } \\
\text { Validated } \\
\text { Relative } \\
\text { Cost }\end{array}$ & $\begin{array}{c}\text { Resu } \\
\text { bstitu } \\
\text { tion } \\
\text { Relati } \\
\text { ve } \\
\text { Cost }\end{array}$ & Complexity & $\begin{array}{l}\text { Tree } \\
\text { Num } \\
\text { ber }\end{array}$ & $\begin{array}{c}\text { Termi } \\
\text { nal } \\
\text { Node } \\
\text { s }\end{array}$ & $\begin{array}{c}\text { Cross- } \\
\text { Validated } \\
\text { Relative } \\
\text { Cost }\end{array}$ & $\begin{array}{c}\text { Resu } \\
\text { bstitu } \\
\text { tion } \\
\text { Relati } \\
\text { ve } \\
\text { Cost }\end{array}$ & Complexity \\
\hline & & 0.0097 & & & & & 0.0099 & & \\
\hline 7 & 86 & $\begin{array}{l}0.73 \pm \\
0.0097\end{array}$ & 0.65 & 0.00022 & 25 & 27 & $\begin{array}{l}0.72 \pm \\
0.0099\end{array}$ & 0.68 & 0.00075 \\
\hline 8 & 80 & $\begin{array}{l}0.73 \pm \\
0.0097\end{array}$ & 0.65 & 0.00024 & $26^{*}$ & 26 & $\begin{array}{l}0.72 \pm \\
0.0099\end{array}$ & 0.68 & 0.00076 \\
\hline 9 & 77 & $\begin{array}{c}0.73 \pm \\
0.0096\end{array}$ & 0.65 & 0.00027 & 27 & 25 & $\begin{array}{c}0.72 \pm \\
0.0099\end{array}$ & 0.68 & 0.00085 \\
\hline 10 & 76 & $\begin{array}{c}0.73 \pm \\
0.0096\end{array}$ & 0.65 & 0.00028 & 28 & 23 & $\begin{array}{c}0.72 \pm \\
0.0099\end{array}$ & 0.68 & 0.00093 \\
\hline 11 & 72 & $\begin{array}{c}0.73 \pm \\
0.0096\end{array}$ & 0.65 & 0.00030 & 29 & 22 & $\begin{array}{l}0.72 \pm \\
0.0099\end{array}$ & 0.68 & 0.00095 \\
\hline 12 & 70 & $\begin{array}{l}0.73 \pm \\
0.0097\end{array}$ & 0.65 & 0.00034 & 30 & 19 & $\begin{array}{c}0.72 \pm \\
0.0099\end{array}$ & 0.68 & 0.00096 \\
\hline 13 & 53 & $\begin{array}{l}0.73 \pm \\
0.0097\end{array}$ & 0.66 & 0.00037 & 31 & 16 & $\begin{array}{l}0.72 \pm \\
0.0099\end{array}$ & 0.69 & 0.00099 \\
\hline 14 & 47 & $\begin{array}{l}0.73 \pm \\
0.0097\end{array}$ & 0.66 & 0.00039 & 32 & 15 & $\begin{array}{l}0.72 \pm \\
0.0099\end{array}$ & 0.69 & 0.0010 \\
\hline 15 & 45 & $\begin{array}{l}0.73 \pm \\
0.0097\end{array}$ & 0.67 & 0.00040 & 33 & 13 & $\begin{array}{c}0.72 \pm \\
0.0098\end{array}$ & 0.69 & 0.0013 \\
\hline 16 & 44 & $\begin{array}{l}0.73 \pm \\
0.0097\end{array}$ & 0.67 & 0.00043 & 34 & 11 & $\begin{array}{c}0.73 \pm \\
0.0098\end{array}$ & 0.70 & 0.0017 \\
\hline 17 & 41 & $\begin{array}{l}0.73 \pm \\
0.0097\end{array}$ & 0.67 & 0.00046 & 35 & 10 & $\begin{array}{c}0.73 \pm \\
0.0096\end{array}$ & 0.70 & 0.0024 \\
\hline 18 & 40 & $\begin{array}{l}0.73 \pm \\
0.0097\end{array}$ & 0.67 & 0.00047 & 36 & 9 & $\begin{array}{l}0.73 \pm \\
0.0095\end{array}$ & 0.70 & 0.0024 \\
\hline 19 & 39 & $\begin{array}{l}0.73 \pm \\
0.0097\end{array}$ & 0.67 & 0.00049 & 37 & 8 & $\begin{array}{l}0.73 \pm \\
0.0095\end{array}$ & 0.70 & 0.0031 \\
\hline 20 & 36 & $\begin{array}{c}0.73 \pm \\
0.0098\end{array}$ & 0.67 & 0.00052 & 38 & 7 & $\begin{array}{l}0.73 \pm \\
0.0095\end{array}$ & 0.71 & 0.0032 \\
\hline 21 & 34 & $\begin{array}{c}0.73 \pm \\
0.0098\end{array}$ & 0.67 & 0.00053 & 39 & 6 & $\begin{array}{c}0.74 \pm \\
0.0094\end{array}$ & 0.71 & 0.0035 \\
\hline 22 & 32 & $\begin{array}{c}0.72 \pm \\
0.0098\end{array}$ & 0.67 & 0.00058 & $40 * *$ & 5 & $\begin{array}{c}0.73 \pm \\
0.0089\end{array}$ & 0.72 & 0.0046 \\
\hline 23 & 30 & $\begin{array}{c}0.72 \pm \\
0.0099\end{array}$ & 0.67 & 0.00062 & 41 & 4 & $\begin{array}{l}0.76 \pm \\
0.0086\end{array}$ & 0.75 & 0.03 \\
\hline 24 & 29 & $0.72 \pm$ & 0.67 & 0.00073 & 42 & 3 & $0.80 \pm$ & 0.80 & 0.04 \\
\hline
\end{tabular}




\begin{tabular}{|c|c|c|c|c|}
\hline $\begin{array}{l}\text { Tree } \\
\text { Num } \\
\text { ber }\end{array}$ & $\begin{array}{c}\text { Termi } \\
\text { nal } \\
\text { Node } \\
\mathrm{s}\end{array}$ & $\begin{array}{c}\text { Cross- } \\
\text { Validated } \\
\text { Relative } \\
\text { Cost }\end{array}$ & $\begin{array}{c}\text { Resu } \\
\text { bstitu } \\
\text { tion } \\
\text { Relati } \\
\text { ve } \\
\text { Cost }\end{array}$ & Complexity \\
\hline & & 0.0052 & & \\
\hline 43 & 2 & $\begin{array}{c}0.90 \pm \\
0.0030\end{array}$ & 0.89 & 0.08 \\
\hline 44 & 1 & $\begin{array}{c}1.00 \pm \\
0.00\end{array}$ & 1.00 & 0.09 \\
\hline
\end{tabular}

Pada gambar di bawah ini disajikan plot hubungan antara banyak simpul akhir dengan kesalahan relatif dari pohon hasil pemangkasan.
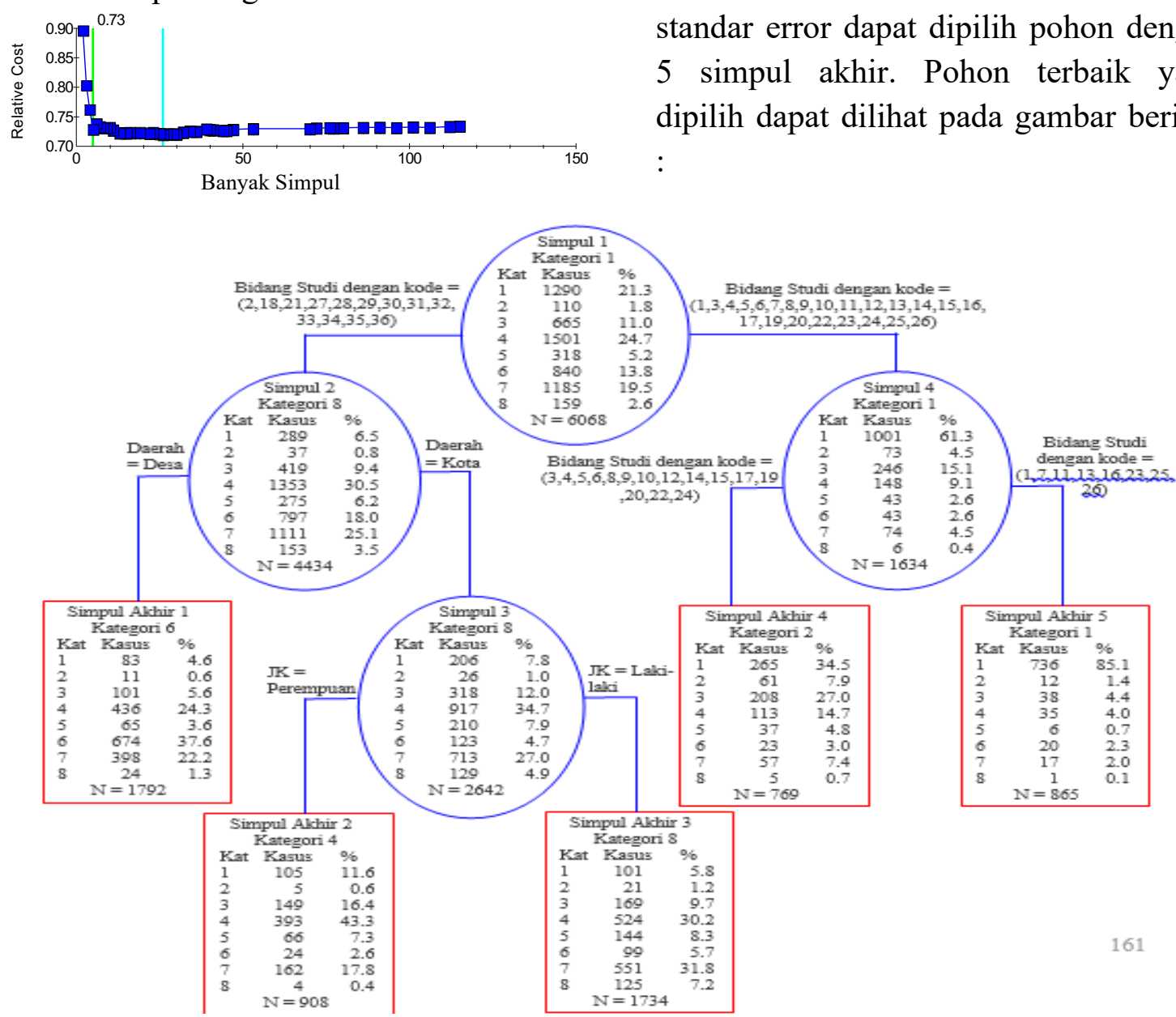

Gambar 4. Pohon Terbaik dari Hasil Pemangkasan
Gambar 3. Plot hubungan jumlah simpul dengan relative cost

Dari Tabel 4 dan Gambar 3 dapat dilihat bahwa pohon yang memiliki kesalahan relatif terkecil adalah pohon dengan 26 simpul akhir. Dengan demikian pohon terbaik berdasarkan kriteria kesalahan relatif adalah pohon dengan 26 simpul akhir. Kesalahan untuk pohon ini berada dalam selang $0,72 \pm$ 0,0099 atau berada dalam selang 0,7101 dan 0,7299. Pada Tabel 4 dapat diketahui bahwa masih terdapat pohon yang lebih kecil dan memiliki nilai kesalahan relatif masih berada dalam selang tersebut yaitu pohon dengan 5 simpul akhir. Dengan demikian, berdasarkan kriteria satu standar error dapat dipilih pohon dengan 5 simpul akhir. Pohon terbaik yang dipilih dapat dilihat pada gambar berikut 
Pohon klasifikasi optimum tersebut mempunyai 1 simpul utama (root node), 3 simpul dalam (internal node) dan 5 simpul akhir (terminal node). Peubah yang menyekat simpul akar adalah bidang studi, sedangkan yang masuk ke simpul dalam adalah peubah daerah tempat tinggal, bidang studi, dan jenis kelamin. Dengan demikian, faktor-faktor yang mempengaruhi jenis pekerjaan masyarakat Sumatera Barat adalah bidang studi, daerah tempat tinggal, dan jenis kelamin. Peubah penjelas lainnya seperti pendidikan tertinggi yang ditamatkan dan pengalaman kerja tidak muncul dalam pemilihan pohon terbaik (optimum). Diduga bahwa pendidikan tertinggi yang ditamatkan sangat erat hubungannya dengan bidang studi, sehingga bidang studi saja sudah cukup mewakili dalam pemilihan pohon terbaik. Pengalaman kerja tidak dapat menjadi peubah penyekat dalam pembentukan pohon optimum diduga disebabkan oleh faktor kehomogenan peubah tersebut.

Berdasarkan Tabel 3 tentang pengkodean peubah yang telah dipresentasikan pada bagian metode penelitian dan juga pada Gambar 4 juga dapat dilihat proses penyekatan sebagai berikut :

\section{Tahap I}

Dari 6068 responden pada simpul 1 dipecah oleh peubah bidang studi menjadi 4434 responden dengan bidang studi administrasi/manajemen bisnis; pelayanan jasa; pertukangan, kerajinan dan industri; lainnya; IPA SMU; IPS SMU; Fisika SMU; Biologi SMU; Bahasa dan Sastra SMU; Listrik, mesin, grafika, tekstil, penerbangan dan lainnya (STM); Ekonomi, akuntansi dan tata niaga (SMEA); Tata boga, tata busana dan tata graha (SMKK); Perhotelan, pariwisata, perawat dan lainnya (SMK) sebagai simpul 2 dan 1634 responden dengan bidang studi agama dan ilmu ketuhanan; administrasi/manajemen keuangan; administrasi pemerintahan; administrasi/manajemen perkantoran; arsitektur dan perencanaan kota; bahasa dan sastra; ekonomi; hukum dan kehakiman; humanisme/humaniora; IPA; IPS; kedokteran dan kesehatan; kehutanan; kesenian dan seni rupa; komunikasi massa dan dokumentasi; matematika dan ilmu komputer; perikanan; pertanian; peternakan; psikologi; teknik/teknologi; transportasi dan komunikasi; kependidikan dan keguruan sebagai simpul 4.

\section{Tahap II}

Dari 4434 responden pada simpul 2 dipecah oleh peubah daerah menjadi 1792 responden di pedesaan sebagai simpul akhir 1 dan 2642 responden di perkotaan sebagai simpul 3.

\section{Tahap III}

Dari 2642 responden pada simpul 3 dipecah oleh peubah jenis kelamin menjadi 908 responden perempuan sebagai simpul akhir 2 dan 1734 responden laki-laki sebagai simpul akhir 3.

4. Tahap IV

Dari 1634 responden pada simpul 4 dipecah oleh peubah bidang studi menjadi 769 responden dengan bidang studi administrasi/manajemen keuangan; administrasi pemerintahan; administrasi/manajemen perkantoran; arsitektur dan perencanaan kota; bahasa dan sastra; ekonomi; hukum dan kehakiman; humanisme/humaniora; IPS; kehutanan; kesenian dan seni rupa; matematika dan ilmu komputer; perikanan; pertanian; peternakan; teknik/teknologi 
sebagai simpul akhir 4 dan 865 responden dengan bidang studi agama dan ilmu ketuhanan; IPA; kedokteran dan kesehatan; komunikasi massa dan dokumentasi; psikologi; transportasi dan komunikasi; kependidikan dan keguruan sebagai simpul akhir 5.

Berdasarkan hasil analisis data pada gambar 3 diperoleh 5 simpul akhir yang berarti terdapat 5 kelompok masyarakat yang mempunyai pekerjaan utama dengan pendidikan tertinggi yang ditamatkan minimal SMU sederajat yaitu :

a. Simpul akhir 1 : Kelompok masyarakat dengan bidang studi administrasi/manajemen bisnis; pelayanan jasa; pertukangan, kerajinan dan industri; lainnya; IPA SMU; IPS SMU; Fisika SMU; Biologi SMU; Bahasa dan Sastra SMU; Listrik, mesin, grafika, tekstil, penerbangan dan lainnya (STM); Ekonomi, akuntansi dan tata niaga (SMEA); Tata boga, tata busana dan tata graha (SMKK); Perhotelan, pariwisata, perawat dan lainnya (SMK) di daerah pedesaan didominasi oleh jenis pekerjaan tenaga usaha tani, kebun, ternak, ikan, hutan dan perburuan sebesar $37,6 \%$.

b. Simpul akhir 2 : Kelompok masyarakat dengan bidang studi administrasi/manajemen bisnis; pelayanan jasa; pertukangan, kerajinan dan industri; lainnya; IPA SMU; IPS SMU; Fisika SMU; Biologi SMU; Bahasa dan Sastra SMU; Listrik, mesin, grafika, tekstil, penerbangan dan lainnya (STM); Ekonomi, akuntansi dan tata niaga (SMEA); Tata boga, tata busana dan tata graha (SMKK); Perhotelan, pariwisata, perawat dan lainnya (SMK) berjenis kelamin perempuan didominasi oleh jenis pekerjaan tenaga usaha penjualan sebesar 43,3\%.

c. Simpul akhir 3 : Kelompok masyarakat dengan bidang studi administrasi/manajemen bisnis; pelayanan jasa; pertukangan, kerajinan dan industri; lainnya; IPA SMU; IPS SMU; Fisika SMU; Biologi SMU; Bahasa dan Sastra SMU; Listrik, mesin, grafika, tekstil, penerbangan dan lainnya (STM); Ekonomi, akuntansi dan tata niaga (SMEA); Tata boga, tata busana dan tata graha (SMKK); Perhotelan, pariwisata, perawat dan lainnya (SMK) berjenis kelamin laki-laki didominasi oleh jenis pekerjaan TNI dan POLRI sebesar $31,8 \%$.

d. Simpul akhir 4 : Kelompok masyarakat dengan bidang studi administrasi/manajemen keuangan; administrasi pemerintahan; administrasi/manajemen

perkantoran; arsitektur dan perencanaan kota; bahasa dan sastra; ekonomi; hukum dan kehakiman; humanisme/humaniora; IPS; kehutanan; kesenian dan seni rupa; matematika dan ilmu komputer; perikanan; pertanian; peternakan; teknik/teknologi didominasi oleh jenis pekerjaan tenaga profesional, teknisi, dan tenaga lain ybdi sebesar 34,5\%.

e. Simpul akhir 5: Kelompok masyarakat dengan bidang studi agama dan ilmu ketuhanan; IPA; 
kedokteran dan kesehatan; komunikasi massa dan dokumentasi; psikologi; transportasi dan komunikasi; kependidikan dan keguruan didominasi oleh jenis pekerjaan tenaga profesional, teknisi, dan tenaga lain ybdi sebesar $85,1 \%$.

Pada pohon terbaik dari hasil pemangkasan terdapat kesalahan pengelompokkan (misclassification) yang dapat dilihat pada Tabel 5 berikut :

Tabel 5. Kesalahan pengelompokkan

\begin{tabular}{|c|c|c|c|c|}
\hline $\begin{array}{l}\mathrm{Ka} \\
\text { teg } \\
\text { ori }\end{array}$ & $\begin{array}{c}\text { Kateg } \\
\text { ori }\end{array}$ & $\begin{array}{l}\text { Kesalah } \\
\text { an } \\
\text { Pengelo } \\
\text { mpokka } \\
\text { n }\end{array}$ & $\begin{array}{l}\text { Persent } \\
\text { ase } \\
\text { Error }\end{array}$ & $\begin{array}{l}\text { Peluan } \\
\text { g }\end{array}$ \\
\hline 1 & 1290 & 554 & 42.95 & 0.43 \\
\hline 2 & 110 & 49 & 44.55 & 0.45 \\
\hline 3 & 665 & 665 & 100 & 1 \\
\hline 4 & 1501 & 1108 & 73.82 & 0.74 \\
\hline 5 & 318 & 318 & 100 & 1 \\
\hline 6 & 840 & 166 & 19.76 & 0.2 \\
\hline 7 & 1185 & 1185 & 100 & 1 \\
\hline 8 & 159 & 34 & 21.38 & 0.21 \\
\hline
\end{tabular}

Berdasarkan Tabel 5 dapat dilihat bahwa dari 1290 responden dengan kategori 1 terjadi kesalahan pengelompokkan sebanyak 554 responden. Dari 110 responden dengan kategori 2 terjadi kesalahan pengelompokkan sebanyak 49 responden. Dari 1501 responden dengan kategori 4 terjadi kesalahan pengelompokkan sebanyak 1108 responden. Dari 840 responden dengan kategori 6 terjadi kesalahan pengelompokkan sebanyak 166 responden. Dari 159 responden dengan kategori 8 terjadi kesalahan pengelompokkan sebanyak 34 responden. Pada kategori 3, 5 dan 7 , semua responden terjadi kesalahan pengelompokkan.

\section{KESIMPULAN}

Jenis pekerjaan di Sumatera Barat diduga dipengaruhi oleh faktor daerah tempat tinggal, jenis kelamin, bidang studi, pendidikan tertinggi yang ditamatkan, dan pengalaman kerja. Dari kelima faktor tersebut yang telah diidentifikasi menggunakan metode pohon klasifikasi pada CART (Classification \& Regression Trees) diperoleh 3 faktor yang mempengaruhi jenis pekerjaan penduduk Sumatera Barat yaitu bidang studi, daerah tempat tinggal dan jenis kelamin. Selain itu, diperoleh pohon klasifikasi optimum dengan 5 simpul akhir yang berarti terdapat 5 kelompok masyarakat yang mempunyai pekerjaan utama, dimana 2 kelompok diantaranya didominasi oleh jenis pekerjaan tenaga professional, teknisi dan tenaga lain yang berkaitan.

\section{DAFTAR PUSTAKA}

[1]. Badan Pusat Statistik. (2002). Klasifikasi Baku Jenis Pekerjaan Indonesia (KBJI). Jakarta-Indonesia: Badan Pusat Statistik.

[2]. Darsyah, M.Y. (2013). Menakar tingkat akurasi support vector machine study kasus kanker payudara. Jurnal Statistika Universitas Muhammadiyah Semarang, 1(1).

[3]. Sumartini, Siti Holis. (2015). Penggunaan Metode Classification 
and Regression Trees (CART) Untuk Klasifikasi Rekurensi Pasien Kanker Serviks di RSUD Dr. Soetomo Surabaya. Jurnal Sains dan Seni ITS, 4(2).

[4]. Inayah, Riza. (2014). Klasifikasi Rumah Tangga Miskin di Kabupaten Jombang Berdasarkan Faktor-faktor yang Mempengaruhi dengan Pendekatan CART (Classification and Regression Trees). Jurnal Sains dan Seni ITS, 3(2).

[5]. Badan Pusat Statistik. (2004). Statistik Kesejahteraan Rakyat (Welfare Statistics). JakartaIndonesia: Badan Pusat Statistik.
[6]. Breiman L, Friedman J, Olshen R, dan Stone C. (1993). Classification and Regression Trees. New YorkLondon : Chapman Hall.

[7]. Lewis, R J. (2000). An Introduction to Classification And Regression Trees (CART) Analysis. TorranceCalifornia : Departement of Emergency Medicine Harbor-UCLA Medical Center.

[8]. Susanti, Reni. (2008). Pohon Klasifikasi untuk Menduga Faktorfaktor yang Mempengaruhi Keberhasilan Siswa di SPMB. Tesis$S 2$, tidak diterbitkan. 